\title{
Extent of Forest Depletion from 1986-2015 as a Consequence of Land use in Andoni Local Government Areas of Rivers State, Nigeria
}

\author{
*ELUDOYIN, OS; UGBANA, T; OTALI, SO
}

\author{
Department of Geography and Environmental Management, University of Port Harcourt, Port Harcourt, Nigeria \\ *Corresponding Author Email: olatunde.eludoyin@uniport.edu.ng
}

\begin{abstract}
The study investigated the extent of forest depletion between 1986 and 2015 in Andoni LGA, Rivers State, Nigeria. Landsat images of 1986, 2000 and 2015 were employed for the study. Image classifications were done in Erdas Imagine using supervised classification with maximum likelihood module whereby six major classes of landuse were identified namely forest, built up area, waterbodies, mangrove, cultivated land, and bareground/sand. The area in square kilometers of each land use type in each year was computed in ArcGIS 10.0 and simple calculations were used to compute the change and percentage change of each landuse from one period to the other. Landuse probability of change to other landuse in 2025, 2035 and 2045 were done Idrisi Selva 17.0. Findings showed that forest coverage was 125.95 $\mathrm{km}^{2}(39.56 \%)$ in 1986 and $74.14 \mathrm{~km}^{2}(23.29 \%)$ in 2015 . Forest, cultivated land, and waterbodies decreased by $41.14 \%$, $80.8 \%$ and $76.52 \%$ while built up area, mangrove and bareground/sand increased by $303.64 \%, 18.67 \%$ and $3.64 \%$ from 1986 to 2015 . Bareground/sand and built-up areas replaced forest with $21.23 \mathrm{~km}^{2}(38.40 \%)$ and $20.26 \mathrm{~km}^{2}(3.64 \%)$ respectively. The study predicted that $3.68 \%$ of bareground/sand, $0.47 \%$ of mangrove and $3.51 \%$ of built up area had probability of replacing forest by 2025 while $5.09 \%, 2.1 \%$ and $7.32 \%$ of bareground/sand, mangrove and built up area had the probability of changing to forest by 2045 . The study recommended that strict legislation, policies and strategies should be put in place to protect the forests from undue exploitation.
\end{abstract}

DOI: https://dx.doi.org/10.4314/jasem.v23i6.11

Copyright: Copyright $(\mathrm{C} 2019$ Eludoyin et al. This is an open access article distributed under the Creative Commons Attribution License (CCL), which permits unrestricted use, distribution, and reproduction in any medium, provided the original work is properly cited.

Dates: Received: 27 April 2019; Revised: 22 May 2019; Accepted 11 June 2019

Keywords: Forest depletion; geo-information; supervised classification; Andoni LGA

Deforestation is becoming a global problem in recent time, periodic monitoring of the spatial coverage of forest is inevitable. Overall, there was a net decrease in global forest area of 3\% between 1990 and 2015, from $4128 \mathrm{M}$ ha to $3999 \mathrm{M}$ ha, with natural and human-induced deforestation being offset by increases in forest area that had both natural and human causes (Keenan et al., 2015). At the present time, the forest loss has decreased to approximately 13 million hectares per year (Forkuo and Frimpong, 2012). The largest net loss of forest occurs in South America and Africa and reports showed that about 4.0 million hectares per year were lost between 2000 and 2010 . The net loss of forests has been significantly reduced, mainly because of several projects including forest planting, restoration of landscape and natural expansion of forests (FAO, 2012). It was reported in Lambin et al (2003) that forest degradation was most extensive in Southeast Asia ( $0.42 \%$ per year), lowest in Latin America ( $0.13 \%$ per year), and intermediate in Africa $(0.21 \%$ per year). Forest area has declined in Central America, South America, South and Southeast Asia and all three regions in Africa between 2010 and 2015 (Keenan et al. 2015). For instance, net loss of forest area between 2010 and 2015 in South America was dominated by Brazil (984 $\mathrm{K}$ ha $\mathrm{y}^{-1}$ ), also significant net losses were recorded in Paraguay ( 325 $\mathrm{K}$ ha $\mathrm{y}^{-1}$ ), Argentina (297 K ha $\left.{ }^{-1}\right)$, Bolivia (289 K ha $\left.\mathrm{y}^{-1}\right)$ and Peru (187 K ha $\mathrm{y}^{-1}$ ) (Keenan et al., 2015). In South and Southeast Asia, the rate of net forest loss

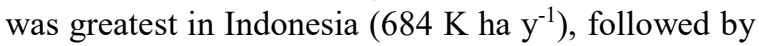
Myanmar, where the loss rate of $546 \mathrm{~K}$ ha y1 between 2010 and 2015 was $25 \%$ higher than in the 1990 s (Keenan et al, 2015). In Africa, the greatest net losses in forest area between 2010 and 2015 were in Nigeria $\left(410 \mathrm{~K}\right.$ ha $\left.\mathrm{y}^{-1}\right)$, Tanzania (372 $\mathrm{K}$ ha $\mathrm{y}^{-1}$ ), Zimbabwe (312 K ha $\mathrm{y}^{-1}$ ) and Democratic Republic of Congo (311 K ha $\mathrm{y}^{-1}$ ) (Keenan et al, 2015). Having seen the rate of forest degradation in Africa in which Andoni LGA is inclusive and some parts of the world, it is important to monitor and quantify the spatio-temporal changes of forest cover and other landuse types. Technological progress allows a comprehensive understanding of any region of the earth's surface from satellite images (Chuvieco et al., 2012). These images of the earth have been widely used for change detection, specifically to the mapping and monitoring deforestation and forest degradation. Forest resource maps were traditionally prepared from forest inventories, involving aerial photography and 
fieldwork (Fabiyi, 2001). Remote sensing and geographical information system have been proven to be excellent techniques for studying the environment, offering facilities for combining different maps, variables and data for diverse sources as well as predictive analysis and trend assessment of events (Lambin and Geist, 2006). Hacke (2012) used geoinformation technologies in detecting oil spill; and Mahesk (2008) monitored and modelled urban sprawl using geo-information technologies. However, several studies had been done with the use of geo-information technologies to assess landuse change especially monitoring deforestation over time. These included Hansen et al (2003) which reported that 1.6 billion hectares tropical forest globally has reduced over time due to urbanization and settlement using geoinformation technologies. Adia and Rabiu (2007) investigated the spatio-temporal change detection of vegetation cover of Jos and its surrounding areas while Eludoyin et al. (2009) used GIS and remote sensing to assess the landuse change of Obio/Akpor LGA of Rivers State, revealing that farmland, mangrove, primary forest and sparse vegetation had reduced over time. Ochege et al. (2014) assessed forest degradation in Sagbama, Bayelsa State using landsat images between 1987 and 2013 with the study showing that there was a reduction in the spatial extent of vegetation cover. None of these studies was done to assess forest depletion over time in Andoni LGA suggesting that studies on deforestation monitoring in Andoni LGA is rare in the literature. The present study therefore investigated the landuse change between 1986 and 2015 with a view to monitoring deforestation in Andoni LGA, Rivers State, Nigeria.

\section{MATERIALS AND METHODS}

Study Area: The study area was Andoni LGA, Rivers State, Nigeria. Andoni Local Government Area is located between latitudes $4^{\circ} 27^{\prime} 30^{\prime \prime} \mathrm{N}$ and $4^{\circ} 35^{\prime} 30^{\prime \prime} \mathrm{N}$ and longitudes $7^{\circ} 17^{\prime} 30^{\prime \prime} \mathrm{E}$ and $7^{\circ} 32^{\prime} 30^{\prime \prime} \mathrm{E}$ (Figure 1). Andoni LGA is bounded in the north by Khana LGA, in the south by Atlantic Ocean, in the east by Opobo/Nkoro LGA and west by Bonny LGA. Andoni LGA is situated in sub-equatorial region. The study area has a mean annual temperature of $28^{\circ} \mathrm{C}$ with the lowest month of not less than $25^{\circ} \mathrm{C}$ and the hottest of about $31^{\circ} \mathrm{C}$. The annual range of temperature is $3.8^{\circ} \mathrm{C}$. Andoni LGA enjoys monsoon climate with high rainfall of about $2500 \mathrm{~mm}$ annually and relative humidity of about $85 \%$. The moist south east air blows over the region between February and November and the region receives its rain while the north east trade wind blows over the region in the months of November through February which ushers in the dry season (Eludoyin et al, 2015). The study area is endowed with high forest and mangrove. Rainforest tree species include Mahogany, Militia excelsa, and Triplochiton scleroxylon. The mangrove swamp forests included Rhizophora sp. and Nypa fruticans. The topography of the area is flat terrain with very gentle slopes with an elevation less than $15 \mathrm{~m}$ above mean sea level. The soil of Andoni LGA is predominantly sandy and also endowed with sandy beach-ridges which cause alternating lower and higher lands. The ecological zone of Andoni area is salt water swamp and the major occupation in Andoni LGA was fishing and farming.

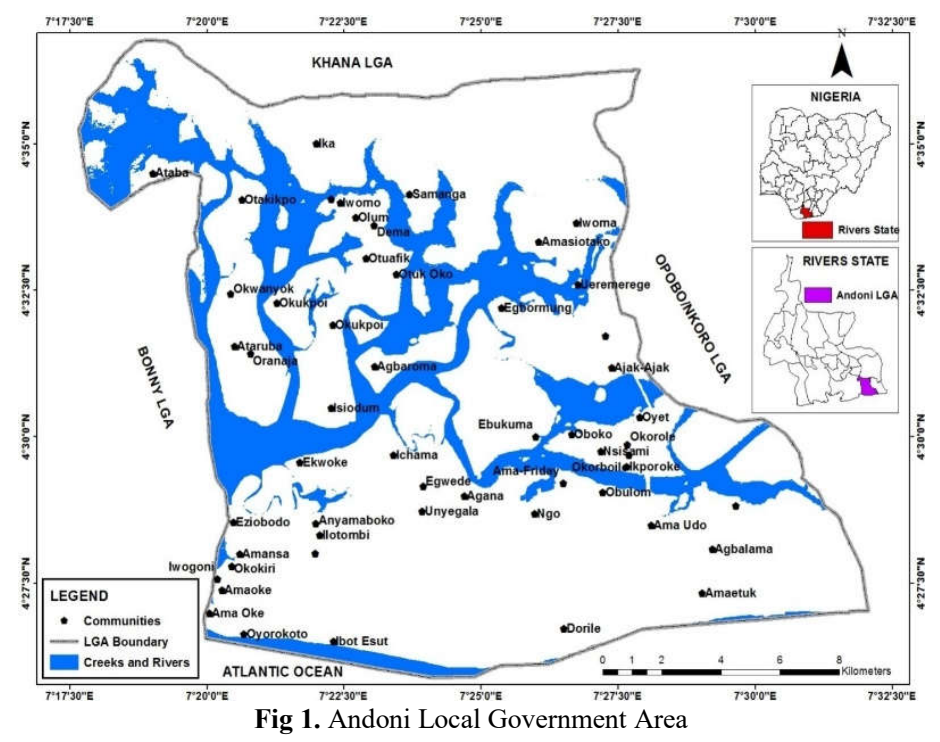

Image geo-processing, Landuse change and Percentage change: The study made use multi-

spectral satellite images of Landsat TM 5, ETM 7 and ETM 7; all having some characteristics presented in 
Table 1. Landsat images were used because of their ability to have valuable and continuous records of the earth's surface for identifying and monitoring changes in man-made and physical environments (El Bastawesy, 2014; USGS, 2014; Ramat and Kumar, 2017). The images were enhanced by combining all the image bands using layer stack module in Erdas Imagine 9.2 and a false colour composite image of 7 , 4 , and 2 was selected for each year for further studies. Band sequence 7, 4, 2 RGB is good to be used for classifying the land cover (Cummings, 2007) and moreso the band combination has the capabilities to clearly define different vegetation types (Geospatial Innovation Facility, 2008). Furthermore, Enaruvbe and Atafo (2014) confirmed that a combination of channel 5 (red), channel 4 (green) and channel 2 (blue) is effective in discriminating different vegetal cover types. Cohen and Goward (2004) also showed the importance of the shortwave infrared channels in characterizing vegetation. Information from each land cover classes was collected from extensive field survey before the classification of satellite imageries (Balogun et al., 2011; Enaruvbe and Atedhor, 2015). The field survey was performed throughout Andoni LGA of Rivers State using global positioning system (GPS). The GPS has developed into an efficient GIS data collection technology which in order to acquire datasets directly from the field which forms part of ground truthing (Balogun et al., 2011). The field work was conducted in between December, 2015 and January, 2016; to tally with the season during which the imageries were obtained. A total of one hundred and ninety three sample locations were determined within all the categories.

In this study, accuracy assessment was performed for the classified maps of 1986, 2000, and 2015. The accuracy assessment is the most often used statistical measure of classification accuracy of satellite imageries (Enavrube and Atafo, 2014) and it is essentially a measure of how many ground truth pixels were classified correctly (Gessesse, 2007). Overall accuracy, user's and producer's accuracies and the Kappa statistics were derived from the error matrices to find the reliability and accuracy of the maps produced (Manandhar et al., 2009). The error matrix is described as the starting point for a variety of descriptive and analytical statistical techniques for accuracy assessment (Congalton, 1991); and this was generated in Idrisi Selva software. Thus, overall accuracy was computed by dividing the total correctly classified pixels by the total number of pixels in the error matrix (Congalton, 1991; Enavrube and Atedhor, 2015).

The Kappa coefficient lies typically on a scale between 0 (no reduction in error) and 1 (complete reduction of error) (Forkuo and Frimpong, 2012). Kappa values are characterized into 3 groupings: a value greater than $0.80(80 \%)$ represents strong agreement, a value between 0.40 and 0.80 (40 to $80 \%$ ) represents moderate agreement, and a value below $0.40(40 \%)$ represents poor agreement (Congalton, 1991; Forkuo and Frimpong, 2012).

Supervised classification using maximum likelihood algorithm classifiers in Erdas Imagine 9.2 (Lillesand and Kiefer, 1994) was used to classify similar spectral signatures into various classes which included forest, mangrove, water bodies, built-up area, cultivated land and bare soil/sand. Maximum likelihood classifier was chosen because it is the most widely adopted parametric classification algorithm (Manandhar et al., 2009). The area of each landuse class was calculated in ArcGIS 10.0 which was used to compute the landuse change and percentage change in squared kilometers. The percentage change was computed using equation (1) as given in Enaruvbe and Atedhor (2015).

$$
\frac{\left(\frac{d}{t 1}\right) * 100}{y 2-y 1} \quad \ldots \ldots \ldots \ldots \ldots \ldots \ldots \ldots \ldots
$$

Where, $d$ is the difference in the value of area covered by a land cover category at the initial time point and final time point, $t_{1}$ is the value of the area covered by a land cover category in the initial time point, $\mathrm{y} 1$ and y2 are base year and final year respectively.

The probability of landuse changing to another in the next 10 years (2025), 20 years (2035) and 30 years (2045) was done using Markov's Transition Estimator in Idrisi Selva 17.0. The extent at which other landuse types have reduced the forest landuse in 2000 and 2015 was computed in ArcGIS 10.0 using overlay method with INTERSECT operator. The INTERSECT-based overlay method gives room for the landuse of a year to be overlaid on the landuse of another year.

Table 1. Characteristics of Landsat Images

\begin{tabular}{lllllll}
\hline Year & Date Acquired & Sensor & Cloud Cover (\%) & Path & Row & Resolution \\
\hline 1986 & $19 / 12 / 1986$ & Landsat 5 MSS & 0 & 188 & 57 & $30 \mathrm{~m} \times 30 \mathrm{~m}$ \\
2000 & $17 / 12 / 2000$ & Landsat 7 ETM & 0 & 188 & 57 & $30 \mathrm{~m} \times 30 \mathrm{~m}$ \\
2015 & $09 / 01 / 2015$ & Landsat 7 ETM & 0 & 188 & 57 & $30 \mathrm{~m} \times 30 \mathrm{~m}$ \\
\hline \multicolumn{7}{c}{ Source: US Geological Survey, 2015 }
\end{tabular}


Table 2. Landuse/Landcover Classification Scheme

\begin{tabular}{lll}
\hline S/N & Landuse Types & Description \\
\hline 1 & Forest & Thick forest, Derived forest, mixed forest lands, palms, shrubs, herbs \\
2 & Built Up Area & Residential, commercial and services, industrial, transportation, roads \\
3 & Mangrove & Trees in the swamps and along the creeks or marshy lands \\
4 & Waterbodies & Rivers, permanent open water, lakes, ponds, reservoirs, etc \\
5 & Cultivated land & Agricultural area, crop fields, fallow lands and vegetable lands \\
6 & Bare ground /Sand & Land areas of exposed soil, barren area and open soil without vegetation \\
\hline \multicolumn{2}{c}{ Sources: Adapted from Anderson et al. (2001); Butt et al., (2015) }
\end{tabular}

\section{RESULTS AND DISCUSSION}

Landuse patterns of Andoni LGA between 1986 and 2015: The landuse pattern in 1986, 2000, and 2015 presented in Table 3, Figure 2, Figure 3 and Figure 4 show that in 1986, forest had spatial extent of $125.95 \mathrm{~km}^{2}(39.56 \%)$ of the total land area, built-up area had $14.01 \mathrm{~km}^{2}(4.41 \%)$, cultivated land occupied $22.92 \mathrm{~km}^{2}(7.21 \%)$, mangrove occupied $58.13 \mathrm{~km}^{2}$ $(18.26 \%)$ while bare ground/sand and water body occupied $25.55 \mathrm{~km}^{2}(8.03 \%)$ and $71.71 \mathrm{~km}^{2} \quad(22.53 \%)$ respectively. In 2000, forest had spatial extent of
$100.47 \mathrm{~km}^{2}(31.56 \%)$ of the total land area, built-up area had $16.28 \mathrm{~km}^{2}(5.15 \%)$, cultivated land occupied $22.17 \mathrm{~km}^{2}(6.96 \%)$, mangrove occupied $78.23 \mathrm{~km}^{2}$ (24\%) while bare ground/sand and water body occupied $29.78 \mathrm{~km}^{2} \quad(9.35 \%)$ and $71.34 \mathrm{~km}^{2} \quad(22.41 \%)$ respectively. While in 2015, forest had spatial extent of $74.14 \mathrm{~km}^{2}(23.29 \%)$ of the total land area, built-up area had $56.55 \mathrm{~km}^{2}(17.77 \%)$, cultivated land occupied $4.4 \mathrm{~km}^{2}(1.38 \%)$, mangrove occupied $68.98 \mathrm{~km}^{2}$ $(21.67 \%)$ while bare ground/sand and waterbodies occupied $45.1 \mathrm{~km}^{2} \quad(14.17 \%)$ and $69.1 \mathrm{~km}^{2} \quad(22.72 \%)$ respectively.

Table 3. Spatial extent of landuse in Andoni between 1986 and 2015

\begin{tabular}{lllllll}
\multicolumn{7}{c}{ Table 3. Spatial extent of landuse in Andoni between 1986 and 2015 } \\
\hline Landuse & 1986 & \multicolumn{5}{c}{2015} \\
& Areal Extent & Percentage (\%) & Areal Extent & Percentage (\%) & Areal Extent & Percentage (\%) \\
\hline Forest & 125.95 & 39.56 & 100.47 & 31.56 & 74.14 & 23.29 \\
Built up Area & 14.01 & 4.41 & 16.28 & 5.15 & 56.55 & 17.77 \\
Cultivated land & 22.92 & 7.21 & 22.17 & 6.96 & 4.4 & 1.38 \\
Mangrove & 58.13 & 18.26 & 78.23 & 24.57 & 68.98 & 21.67 \\
Bare ground/sand & 25.55 & 8.03 & 29.78 & 9.35 & 45.1 & 14.17 \\
Water bodies & 71.71 & 22.53 & 71.34 & 22.41 & 69.1 & 21.72 \\
Total & 318.27 & 100.0 & 318.27 & 100.0 & 318.27 & 100.0 \\
\hline
\end{tabular}

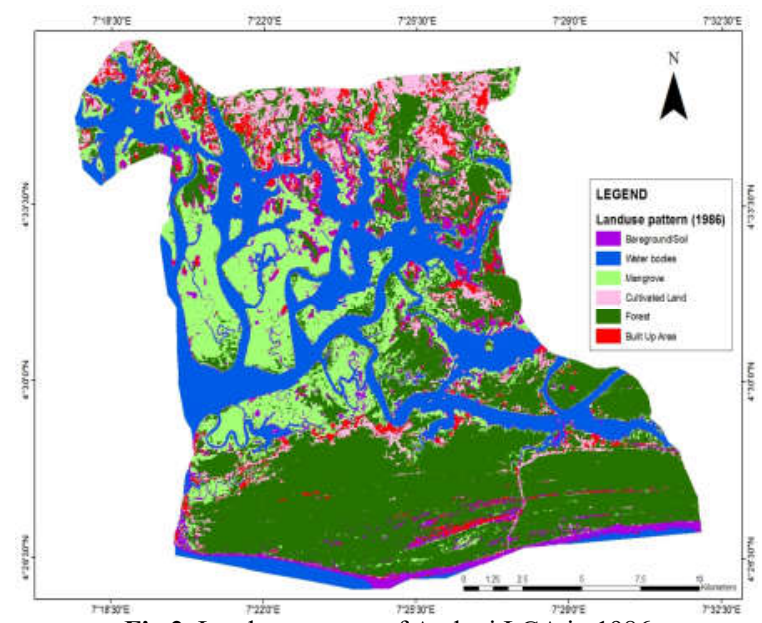

Fig 2. Landuse pattern of Andoni LGA in 1986

Trend and magnitude of landuse change and percentage change of landuse in Andoni LGA between 1986 and 2015: Considering the result of the analysis in Table 4, it is clearly observed that forest, cultivated land, bare soil/sand landuse types reduced by $20.23 \%$, $3.27 \%$, and $0.57 \%$ respectively while built-up area, mangrove and water bodies increased by $16.2 \%$, $16.56 \%$, and $34.58 \%$ respectively between 1986 and 2000 .

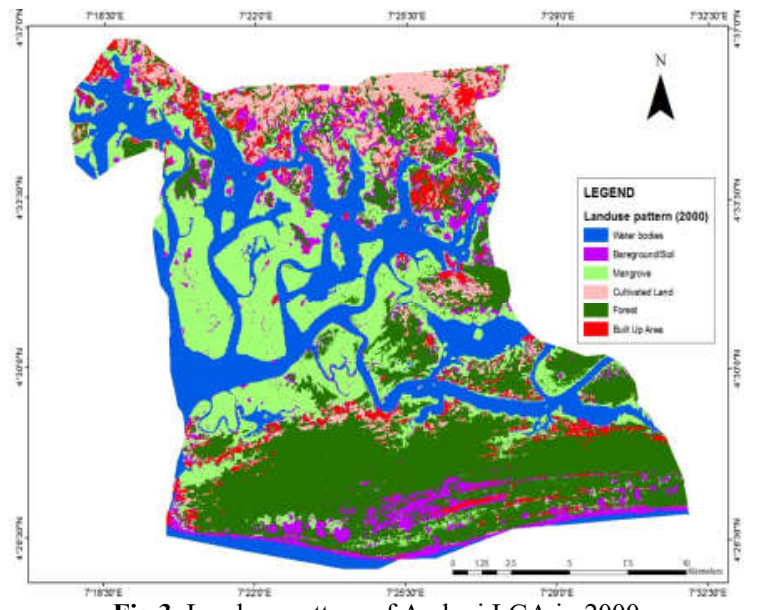

Fig 3. Landuse pattern of Andoni LGA in 2000

The result also shows that forest, built up area, cultivated land, mangrove and water bodies landuse types reduces by $26.21 \%, 247.36 \%, 80.15 \%, 50.77 \%$ and $3.14 \%$ respectively between 2000 and 2015 . The trend analysis shows that forest cover, cultivated land, mangrove and water bodies had reduced between 2000 and 2015. Furthermore, between 1986 and 2015, forest, cultivated land and waterbodies landuse types reduced by $41.14 \%, 80.8 \%$, and $3.64 \%$ respectively. 
On the other hand, built-up area, mangrove and bare ground/sand landuse type increased by $303.64 \%$, $18.67 \%$, and $76.52 \%$ respectively.

Error of Matrix and Accuracy Assessment for Landuse Types: Post-classification accuracy assessment of the data shows an overall accuracy of $91.7 \%$ in 1986, $91.5 \%$ in 2000 and $87.6 \%$ in 2015 (Table 6). Similarly, the Kappa statistics in 1986, 2000 and 2015 are 0.84 (84\%), $0.85(85 \%)$ and $0.86(86 \%)$ respectively (Table $6)$. The results of overall accuracy assessment and Kappa statistics indicated a strong agreement or accuracy between the classified maps and the ground reference information ((Manandhar et al., 2009).

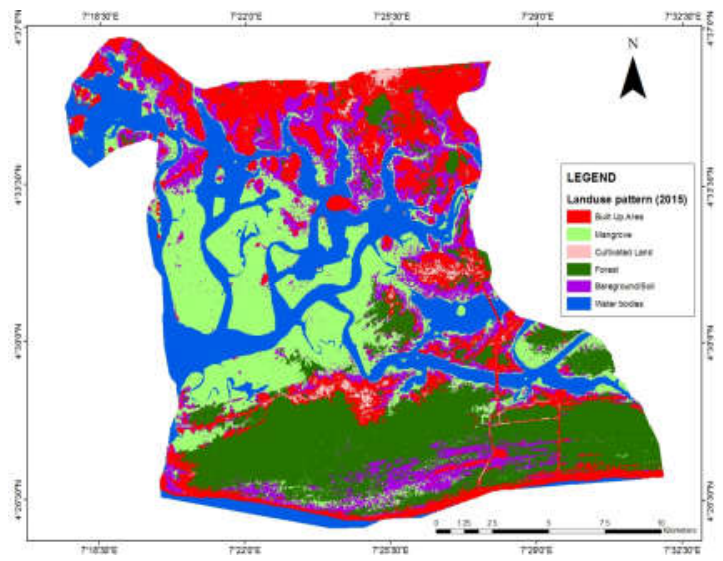

Fig 4. Landuse pattern of Andoni LGA in 2015

Table 4. Trend and magnitude of landuse change and percentage change in Andoni LGA between 1986 and 2015

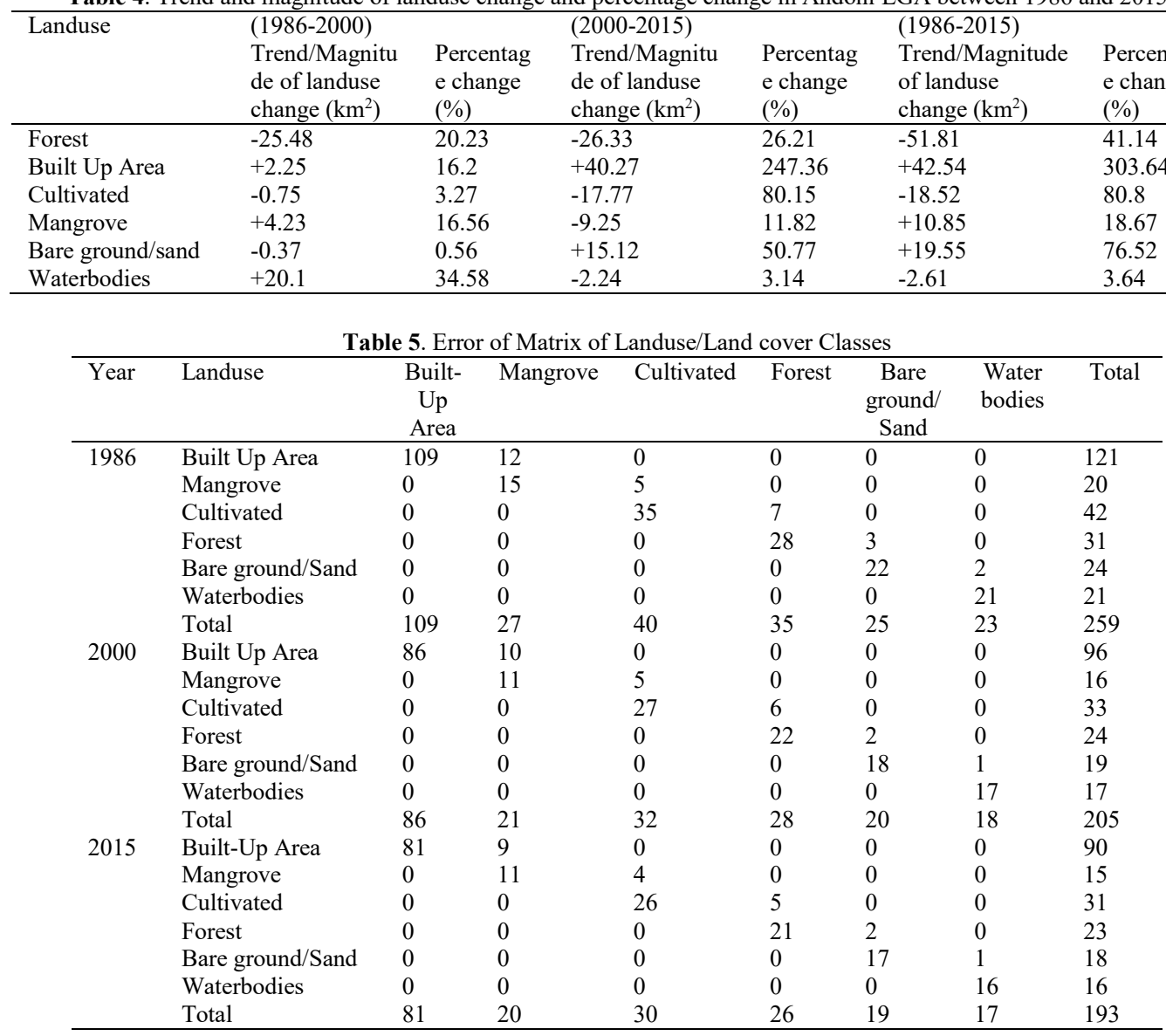

Spatial Extent of Other Landuse into Forest Landuse between 1986 and 2015: The spatial extent of forest landuse captured by water bodies, bareground/sand, mangrove, cultivated land and built up area in Andoni LGA between 1986 and 2015 is presented in Table 5. It was shown that between 1986 and 2000 , water bodies captured $0.02 \mathrm{~km}^{2}(0.06 \%)$, bareground/sand captured $9.15 \mathrm{~km}^{2}(26.72 \%)$, mangrove $13.7 \mathrm{~km}^{2}$ (40\%), cultivated land $6.77 \mathrm{~km}^{2}(19.77 \%)$ while built up area captured $4.61 \mathrm{~km}^{2}(13.46 \%)$. Furthermore, between 2000 and 2015, water bodies captured 0.001 $\mathrm{km}^{2}(0.003 \%)$, bare ground/sand captured $13.94 \mathrm{~km}^{2}$ (41.11\%), mangrove $4.63 \mathrm{~km}^{2}(13.65 \%)$, cultivated land $1.13 \mathrm{~km}^{2}(3.33 \%)$ while built up area captured $14.21 \mathrm{~km}^{2}$ (41.91\%). From 1986 to 2015, water bodies captured $0.15 \mathrm{~km}^{2}(0.27 \%)$, bare ground/sand captured $21.23 \mathrm{~km}^{2}(38.40 \%)$, mangrove $11.90 \mathrm{~km}^{2}(21.52 \%)$, cultivated land $1.75 \mathrm{~km}^{2}(3.17 \%)$ while built up area 
captured $20.26 \mathrm{~km}^{2}$ (36.64 \%). Thus, the total spatial extent of forest landuse lost to other landuse types between 1986 and 2000 was $34.25 \mathrm{~km}^{2}$ while it was $33.91 \mathrm{~km}^{2}$ between 2000 and 2015 .

Table 6. Accuracy assessment for the supervised classified image

\begin{tabular}{lllllll}
\hline Year & Class name & $\begin{array}{l}\text { Reference } \\
\text { total }\end{array}$ & $\begin{array}{l}\text { Classified } \\
\text { total }\end{array}$ & $\begin{array}{l}\text { Number } \\
\text { correct }\end{array}$ & $\begin{array}{l}\text { Producer's } \\
\text { Accuracy (\%) }\end{array}$ & $\begin{array}{l}\text { User's } \\
\text { Accuracy }(\%)\end{array}$ \\
\hline 1986 & Built-up & 86 & 96 & 83 & 96.51 & 86.46 \\
& Mangrove & 21 & 16 & 16 & 76.19 & 100.00 \\
& Cultivated & 32 & 33 & 31 & 96.88 & 93.94 \\
& Forest & 28 & 24 & 23 & 82.14 & 95.83 \\
& Bare soil/sand & 20 & 19 & 18 & 90.00 & 94.74 \\
& Waterbodies & 18 & 17 & 17 & 94.44 & 100.00 \\
& Total & 205 & 205 & 188 & & 88.42 \\
2000 & Built-up & 109 & 121 & 107 & 98.17 & 100.00 \\
& Mangrove & 27 & 20 & 20 & 74.07 & 92.86 \\
& Cultivated & 40 & 42 & 39 & 97.50 & 96.77 \\
& Forest & 35 & 31 & 30 & 85.71 & 83.33 \\
& Bare soil/sand & 25 & 24 & 20 & 80.00 & 100.00 \\
& Waterbodies & 23 & 21 & 21 & 91.30 & 86.67 \\
& Total & 259 & 259 & 237 & & 93.33 \\
& Built-up & 81 & 90 & 78 & 96.30 & 83.87 \\
& Mangrove & 20 & 15 & 14 & 75.00 & 95.65 \\
& Cultivated & 30 & 31 & 26 & 86.67 & 83.33 \\
& Forest & 26 & 23 & 22 & 88.46 & 87.50 \\
& Bare soil/sand & 19 & 18 & 15 & 94.74 & \\
Waterbodies & 17 & 16 & 14 & 94.12 & \\
& Total & 193 & 193 & 169 & & \\
\end{tabular}

Overall classification accuracy for 1986 =91.7\%; Kappa statistics $=0.84=84 \%$; Overall classification accuracy for $2000=91.5 \%$; Kappa statistics $=0.85=85 \%$; Overall classification accuracy for $2015=87.6 \%$; Kappa statistics $=0.86=86 \%$

Table 7. Extent of Other Landuse into Forest Landuse between 1986 and 2015

\begin{tabular}{lllllll}
\hline Landuse & $\begin{array}{l}1986-2000 \\
\text { Spatial } \\
\text { Coverage } \\
\left(\mathrm{km}^{2}\right)\end{array}$ & $\begin{array}{l}\text { Percentage } \\
(\%)\end{array}$ & $\begin{array}{l}\text { 2000-2015 } \\
\text { Spatial } \\
\text { Coverage } \\
\left(\mathrm{km}^{2}\right)\end{array}$ & $\begin{array}{l}\text { Percentage } \\
(\%)\end{array}$ & $\begin{array}{l}\text { Spatial } \\
\text { Coverage } \\
\left(\mathrm{km}^{2}\right)\end{array}$ & $\begin{array}{l}\text { Percentage } \\
(\%)\end{array}$ \\
\hline Waterbodies & 0.02 & 0.06 & 0.001 & 0.003 & 0.15 & 0.27 \\
Bareground/sand & 9.15 & 26.72 & 13.94 & 41.11 & 21.23 & 38.40 \\
Mangrove & 13.7 & 40.00 & 4.63 & 13.65 & 11.9 & 21.52 \\
Cultivated Land & 6.77 & 19.77 & 1.13 & 3.33 & 1.75 & 3.17 \\
Built Up Area & 4.61 & 13.46 & 14.21 & 41.91 & 20.26 & 36.64 \\
Total & 34.25 & 100.0 & 33.91 & 100.0 & 55.29 & 100.0 \\
\hline
\end{tabular}

Probability of forest landuse changing to other landuse in 2025, 2035 and 2045: The probabilities of forest landuse changing to other landuse types in 2025, 2035 and 2045 in Andoni LGA shown in Table 6 shows that $3.68 \%, 0.47 \%, 6.62 \%$ and $3.51 \%$ of bare ground/sand, mangrove, cultivated land and built up area respectively had a chance of changing to forest landuse while water bodies did not have any chance of capturing forest landuse in 2025. In 2035, findings reveals that water bodies had a chance of $0.03 \%$ of changing to forest landuse, bare ground/sand had $4.72 \%$, mangrove had $1.33 \%$, and cultivated land had $8.06 \%$ while built up area had $6.08 \%$. In 2045 , water bodies had a chance of $0.17 \%$ of changing to forest landuse, bare ground/sand had a chance of $5.09 \%$, and mangrove had $2.10 \%$ while cultivated land and built up area had a chance of $8.75 \%$ and $7.32 \%$ respectively of changing to forest landuse. Findings show that spatial coverage of forest decreased between 1986 and 2015 and this shows that forest land is often tampered with over the years by other landuse. The findings are in agreement with Gessesse (2007) and Egwuogu et al. (2016) whose studies revealed that forest cover changes from time to time because of population growth, urbanization, industrialization, and other form of exploitation. Fabiyi (2011) believed that human actions especially those involving biomass fuel consumption, land-use change, and agricultural activities have direct interaction with the land surface and negative consequences on vegetation and environmental qualities (Fabiyi, 2011). Similarly, Johnson et al. (2002) further stated that overall changes in the landscape show an increased trend for urban development with non-forested vegetation and coastal wetlands suffering the consequences. Adoki (2013) also noted that several forces especially settlement developments and oil prospecting over the years have imprinted indelibly on the Niger Delta which is found in the fragile ecosystem. The reduction in forest cover reduces the significant role that it plays in maintaining the ecosystem. 
Table 8. Probability of forest landuse changing to another landuse in 2025, 2035 and 2045

\begin{tabular}{lllllll}
\hline Landuse classes & Water & Bare soil/sand & Mangrove & Cultivated & Forest & Built-up \\
\hline $\mathbf{2 0 2 5}$ & & & & & & \\
Waterbodies & 0.9335 & 0.0000 & 0.0488 & 0.0000 & 0.0000 & 0.0167 \\
Bare soil/sand & 0.0782 & 0.3661 & 0.2847 & 0.0000 & 0.0368 & 0.2340 \\
Mangrove & 0.0166 & 0.1749 & 0.8033 & 0.0000 & 0.0047 & 0.0000 \\
Cultivated & 0.0000 & 0.0175 & 0.0000 & 0.1163 & 0.0662 & 0.7982 \\
Forest & 0.0000 & 0.1556 & 0.0666 & 0.0140 & 0.6430 & 0.1204 \\
Built Up Area & 0.0000 & 0.1779 & 0.0000 & 0.0337 & 0.0351 & 0.7503 \\
2035 & & & & & & \\
Waterbodies & 0.8720 & 0.0100 & 0.0871 & 0.0004 & 0.0003 & 0.0283 \\
Bare soil/sand & 0.1057 & 0.2320 & 0.3391 & 0.0081 & 0.0472 & 0.2664 \\
Mangrove & 0.0429 & 0.2065 & 0.6959 & 0.0000 & 0.0133 & 0.0404 \\
Cultivated & 0.0000 & 0.1691 & 0.0000 & 0.0422 & 0.0806 & 0.7035 \\
Forest & 0.0073 & 0.1938 & 0.1420 & 0.0148 & 0.4217 & 0.2193 \\
Built Up Area & 0.0076 & 0.2132 & 0.0437 & 0.0307 & 0.0608 & 0.6384 \\
2045 & & & & & & \\
Waterbodies & 0.8160 & 0.0230 & 0.1168 & 0.0008 & 0.0017 & 0.0387 \\
Bare soil/sand & 0.1215 & 0.2010 & 0.3452 & 0.0106 & 0.0509 & 0.2681 \\
Mangrove & 0.0680 & 0.2078 & 0.6198 & 0.0012 & 0.0210 & 0.0807 \\
Cultivated & 0.0078 & 0.2077 & 0.0477 & 0.0305 & 0.0875 & 0.6119 \\
Forest & 0.0219 & 0.2036 & 0.1977 & 0.0151 & 0.2842 & 0.2753 \\
Built Up Area & 0.0217 & 0.2147 & 0.0961 & 0.0265 & 0.0732 & 0.5599 \\
\hline
\end{tabular}

Efiong (2011) reported that forest removal is a factor that enhances global warming that is threatening the environment as the role of plants to reduce the concentration of carbon dioxide in the atmosphere has been defeated. The decrease of forest cover in this study area is an epitome of regional or global forest cover change over a period of time amidst varying reasons which was also reported in Keenan et al. (2015). The reduction in the waterbody and increase in the bareground/sand is similar to the work of Suleiman et al. (2014) which reported that vegetation and water bodies have been greatly tampered with, as a result of human activities through exploitation and development of built up areas. The increase in the bareground/sand over time may be attributed to the reduction in forest cover and infrastructural development in the built up area. Ejaro and Abdullahi (2013) had similar findings with respect to the spatial coverage of bare ground increase between 1987 and 2011 in Suleja LGA, Federal Capital Territory, Nigeria.

Conclusion: The study has demonstrated the roles of geo-information technologies at monitoring forest depletion in Andoni LGA, Rivers State, Nigeria between 1986 and 2015 and it can be concluded that forest landuse had reduced with time and had been replaced mostly by built-up areas. The study therefore recommended that re-afforestation projects should be established to replenish the forests; strict legislation, policies and strategies should be put in place to protect the forests from undue exploitation; and finally, establishment of forest reserve should be encouraged.

\section{REFERENCES}

Adia, SO; Rabiu, AB (2007). Change Detection of Vegetation Cover, using Multi-temporal Remote Sensing Data and GIS Techniques. Available at www.gisdevelopment.net/application/environme $\underline{\mathrm{nt} / \mathrm{ffm} / \mathrm{index} . \mathrm{htm}}$. Accessed on 4th October, 2016.

Adoki, A (2013). Trends in vegetation cover changes in Bonny Area of the Niger Delta, J. Appl. Sci. Environ. Manage. 17(1):89-103.

Anderson, JR; Hardy, EE; Roach, JT; Witmer, RE (2001). A Landuse and Land Cover Classification System for Use with Remote Sensor Data. Geological Survey Professional Paper 964. A revision of the land use classification system as presented in U.S. Geological Survey Circular 671. p.41.

Balogun, IA; Adeyewa, DZ; Balogun, AA; Morakinyo, TE (2011). Analysis of urban expansion and land use changes in Akure, Nigeria, using remote sensing and geographic information system (GIS) techniques. Journal of Geography and Regional Planning. 4(9):533541.

Butt, A; Shabbir, R; Ahmad, SS; Aziz, N (2015). Land use change mapping and analysis using Remote Sensing and GIS: A case study of Simly watershed, Islamabad, Pakistan. The Egyptian Journal of Remote Sensing and Space Sciences. 18:251-259

Chuvieco, E; Aguado, I; Jurdao, S; Pettinari, M; Yebra, M; Salas, J; Hantson, S; de la Riva, J; 
Ibarra, P; Rodrigues, M; Echeverria, M; Azqueta, D; Roman, M; Bastarrika, A; Martinez, S; Recondo, C; Zapico, E; Martinez-Vega, FJ (2012). Integrating geospatial information into fire risk assessment. International Journal of Wildland Fire. 2(2):69-86.

Congalton, RG (1991). A review of assessing the accuracy of classification of remotely sensed data. Remote Sens. Environ. 37:35-46.

Cummings, S (2007). An Analysis of Surface Temperature in San Antonio, Texas. Term Project EE5053/ES4093: Remote Sensing, UTSA. p.11.

Efiong, J (2011). Changing Pattern of Land Use in the Calabar River Catchment, Southeastern Nigeria. Journal of Sustainable Development. 4(1):92102.

Ejaro, SP; Abdullahi, U (2013). Spatio-temporal Analyses of Land Use and Land Cover Changes in Suleja Local Government Area, Niger State, Nigeria. Journal of Environment and Earth Science, 3(9):72-83.

El Bastawesy, M; Ramadan Ali, R; Faid, A; El Osta, $M$ (2013). Assessment of water logging in agricultural megaprojects in the closed drainage basins of the Western Desert of Egypt. J. Hydro. Earth Sys. Sci. 17:1493-1501.

Eludoyin, OS; Wokocha, CC; Ayolagha, G (2010). GIS Assessment of Landuse and Landcover Change in Obio/Akpor LGA, Rivers State. Research Journal of Environmental and Earth Science. 3(4):307-313.

Enaruvbe, GO; Atafo, OP (2014). Analysis of Deforestation Pattern in the Niger Delta Region of Nigeria. Journal of Land use Science. 1-18 DOI: 10.1080/1747423X.2014.965279

Enaruvbe, GO; Atedhor, GO (2015). Spatial Analysis of Agricultural Landuse Change in Asaba, Southern Nigeria. Ife Journal of Science. 17(1):65-74.

Fabiyi, O (2001). Geographic Information Systems, Techniques and Methods. Published by Research Supports Services, Ibadan, Nigeria, p.1-147.

Food and Agricultural Organization (FAO) (2012). Illegal Activities in Forestry.http://www.fao.org/forestry/site/1844/e $\underline{\mathrm{n}}$, Accessed on $24^{\text {th }}$ August, 2016 .
Forkuo, EK; Frimpong, A. (2012). Analysis of Forest Cover Change Detection. International Journal of Remote Sensing Applications. 2(4):82-92.

Gessesse, B (2007). Forest Cover Change and Susceptibility to Forest Degradation Using Remote Sensing and GIS Techniques: A Case of Dendi District, West Central Ethiopia. An unpublished thesis submitted to the School of Graduate Studies of Addis Ababa University. p.107.

Hacke, E (2012). Oil spill detection by remote sensing: A Comparative Legal Analysis. An Unpublished MSc Project submitted to the Department of Public International Law, University of Gent. Available at http://lib.ugent.be/fulltxt/RUG01/001/891/945/R UG01-001891945_2012_0001_AC.pdf. Accessed on $8^{\text {th }}$ April, 2017. 121P

Hansen, MC; DeFries, RS; Townshend, JG; Carroll, M; Dimiceli, C; Sohlberg, R (2003). Global percent tree cover at a spatial resolution of 500 meters: First results of the MODIS vegetation continuous field algorithm. Earth Interactions. $7: 1-15$.

Johnson, AM; Truax, DD; O'Hara, CG; Cartwright, J (2002). Remote sensing, GIS, and Land use and Land cover Mapping along the i-10 corridor. American Society for Photogrammetry and Remote Sensing, p.9.

Keenan, RJ, Reams, GA; Achard, F; de Freitas, JV; Grainger, A; Lindquist E (2015). Dynamics of Global Forest Area: Results from the FAO Global Forest Resources Assessment 2015: Forest Ecology and Management. 352: 9-20.

Lambin, EF; Geist, HJ (2006). Land use and Land Cover Change: Local Processes and Global Impacts (Global Change-IGBP Series). SpringerVerlog; Berlin Heidelberg, Germany: 25

Lambin, EF; Geist, HJ; Lepers, E (2003). Dynamics of Land-use and Land-cover, Change in tropical regions. Annu. Rev. Environ. Resour. 28:205241.

Lillesand, TM; Kieffer, RW (1994). Remote Sensing and Image Interpretation. $3^{\text {rd }}$ Edition, John Wiley and Sons, NewYork.750P.

Mahesk, KJ (2008). Monitoring and modelling of urban sprawl using remote sensing and GIS 
techniques. International Journal of Applied Earth Observation and Geoinformation. 6 (3):2632

Manandhar, R; Odeh, IOA; Ancev, T (2009). Improving the Accuracy of Land Use and Land Cover Classification of Landsat Data Using PostClassification Enhancement. Remote Sens.1, 330344

Ochege, F; Okpala-Okaka, C; Dike, C; George, T (2014). Geospatial Assessment of Forest Degradation in Sagbama, Niger Delta Region of Nigeria. A paper presented at the $35^{\text {th }}$ Annual National Conference of the Nigeria Cartographic Association in Delta State University Abraka, on the $14^{\text {th }}$ August, 2016.
Kaduna State Nigeria using Remote Sensing and GIS. Res. J. Appl. Sci. Engineer. Technol. 2 (2):121-132.

Rawat, JS; Kumar, M (2017). Monitoring land use/cover change using remote sensing and GIS techniques: A case study of Hawalbagh block, district Almora, Uttarakhand, India, Egyptian J. Remote Sensing and Space Sci. 18:7-84.

Suleiman, YM; Saidu, S; Abdulrazaq, SA; Hassan AB; Abubakar, AN (2014). The Dynamics of Land Use Land Cover Change: Using Geospatial Techniques to Promote Sustainable Urban Development in Ilorin Metropolis, Nigeria. Asian Review of Environmental and Earth Sciences. 1(1), 8-15.

Ojonigu, FA; Tabitha, S; Innocent, A; Seidu, OM (2010). Assessing Changes in Kagoro Forest, 